\title{
Neurophysiological aspects of musical auditory stimulation on the cardiovascular system
}

\author{
Aspectos neurofisiológicos do estímulo \\ auditivo musical sobre o sistema cardiovascular
}

Lucas Lima Ferreira ${ }^{1}$, Luiz Carlos Marques Vanderlei ${ }^{1}$, Luiz Carlos de Abreu ${ }^{2}$, Heraldo Lorena Guida ${ }^{3}$, Vitor Engrácia Valenti ${ }^{4}$

${ }^{1}$ Faculdade de Ciência e Tecnologia, Universidade Estadual Paulista “Júlio de Mesquita Filho" (UNESP) - Presidente Prudente (SP), Brazil.

${ }^{2}$ Faculdade de Medicina do ABC (FMABC) - Santo André (SP), Brazil.

${ }^{3}$ Departamento de Fonoaudiologia da Faculdade de Filosofia e Ciências, UNESP - Marília (SP), Brazil.

${ }^{4}$ Faculdade de Filosofia e Ciências, UNESP - Marília (SP), Brazil.

DOI: http://dx.doi.org/10.7322/abcshs.v38i3.24

\begin{abstract}
Introduction: The literature has shown that musical stimulation can influence the cardiovascular system, however, the neurophysiological aspects of this influence are not yet fully elucidated. Objective: This study describes the influence of music on the neurophysiological mechanisms in the human body, specifically the variable blood pressure, as well as the neural mechanisms of music processing. Methods: Searches were conducted in Medline, PEDro, Lilacs and SciELO using the intersection of the keyword "music" with the keyword descriptors "blood pressure" and "neurophysiology". Results: There were selected 11 articles, which indicated that music interferes in some aspects of physiological variables. Conclusion: Studies have indicated that music interferes on the control of blood pressure, heart and respiratory rate, through possible involvement of limbic brain areas which modulate hypothalamic-pituitary functions. Further studies are needed in order to identify the mechanisms by which this influence occurs.
\end{abstract}

Keywords: music; neurophysiology; cardiovascular system.

\section{RESUMO}

Introdução: A literatura já demonstrou que o estímulo musical pode influenciar o sistema cardiovascular, porém, os aspectos neurofisiológicos desta influência ainda não estão totalmente elucidados. Objetivo: Este estudo descreve a influência da música nos mecanismos neurofisiológicos no organismo humano, especificamente na variável pressão arterial, bem como os mecanismos neurais do processamento da música. Métodos: Foram realizadas buscas nas bases Medline, PEDro, SciELO e Lilacs, utilizando o cruzamento da palavra-chave "music" com os descritores "blood pressure" e "neurophysiology". Resultados: Foram selecionados 11 artigos, que indicaram que a música interfere em alguns aspectos nas variáveis fisiológicas. Conclusão: Os estudos demonstraram que a música interfere no controle da pressão arterial, frequência cardíaca e respiratória, por meio do possível envolvimento de áreas límbicas cerebrais, que modulam funções hipotálamo-hipofisárias. Mais estudos são necessários para identificar os mecanismos pelos quais essa influência ocorre.

Palavras-chave: música; neurofisiologia; sistema cardiovascular.

Received: 07/04/2013

Revised: $10 / 15 / 2013$

Accepted: 10/15/2013

Study carried out at the Laboratório de Fisiologia do Estresse, Faculdade de Ciências e Tecnologia, Universidade Estadual Paulista "Júlio de Mesquita Filho" (FCT/UNESP) - Presidente Prudente (SP), Brazil.

Corresponding author

Lucas Lima Ferreira - Laboratório de Fisiologia do Estresse - FCT/UNESP - Rua Roberto Simonsen, 305 - CEP: 19060-900 - Presidente Prudente (SP),

Brasil - E-mail: lucas_lim21@hotmail.com

Financial support: Pró-Reitoria de Pesquisa e Pós-graduação (ProPG) - UNESP.

Conflict of interests: nothing to declare. 


\section{INTRODUCTION}

Currently, music has been used as a therapeutic agent to facilitate, promote and contribute to a better quality of life (QoL) of patients in various specialties - and for that, called music therapy ${ }^{1,2}$ - and it has also been the subject of studies linking their use adjunct to other therapies ${ }^{3-9}$. This therapy involves the skillful use of musical elements in order to improve the physical and mental health of a person, as a way of providing emotional and spiritual support, and in order to reduce stress levels and anxiety ${ }^{1,2}$.

In this context, some authors point out that music can cause different physiological responses, such as changes in blood pressure, heart and respiratory rate, body temperature, galvanic skin responses, biochemical parameters and endocrine emotional changes ${ }^{10,11}$.

In recent years, literature has investigated the relationship between musical stimuli and the cardiovascular system ${ }^{12}$, and has increased the experimental evidence which shows that some types of music can influence cardiac and neurological functions and biochemical reactions, and that it can trigger measurable reduced effects related to stress $^{13}$.

Another source of interest for scientific studies is to explain the neurological level on how the different components of emotional processing of music causally interact. One explanation says that, known for perceiving emotional stimuli (music or other sound), there is an increased activity of the sympathetic nervous system and the somatic nervous system ${ }^{14}$.

Based on the foregoing it is possible to understand the importance of using music as a therapeutic alternative for treatment overall, improving mental health through physiological changes, and based on the absence of original scientific review to identify the role in the musical stimulus neural pathways of the human body, justifying the need for this study. Thus, the objective of this study was to characterize the influence of music on the neurophysiological mechanisms of the human body, specifically the variable blood pressure, as well as identifying the neural mechanisms of processing music.

\section{METHODS}

\section{Selection and characteristics of studies}

It was a literature review with the application of a search strategy to select articles from queries to databases Medline (via PubMed), PEDro, Lilacs and SciELO, with articles published between January of 2000 and December of 2012. Were used to search the intersection of "music" keyword descriptors such as "blood pressure" and "neurophysiology" through the boolean operator "and", which were defined based on the Health Sciences Descriptors (HSD) and its corresponding English language Medical Subject Headings (MeSH).

\section{Criteria for inclusion and exclusion}

We included epidemiological (case series, cross-sectional, case-control or cohort) or experimental studies, published in English, Portuguese or Spanish, available in full, with information which contemplated theme songs and blood pressure, and humans as experimental subject.

Articles that did not contemplate the inclusion criteria, articles published in non-indexed journals, articles that had values less than five in the analysis of methodological quality PEDro, and texts of academic dissertations or theses were excluded.

The full texts of the articles included in the study were evaluated, and their reference lists were checked independently, to identify potential items that could be included in this work, but were not previously found in the electronic search.

\section{Selection strategy}

For the selection of articles, it was initially performed valuing the securities related to the topic in question. This selection was based on the titles, as they approached the main idea of applying some musical stimulation in humans, as well as their influence on the cardiovascular and/or neurological systems, and titles that had the word music or some information concerning this word as a musical style. At the end of the search, we excluded repeated titles, since it was held in various databases. Then detailed summaries of selected articles were read in order to select those that exclusively addressed the topic proposed for this review. With the exception of abstracts that did not address the issue at hand, the full texts were evaluated, and those who fulfilled the inclusion criteria were included as the final result of the search.

\section{Data analysis}

The data were analyzed qualitatively and presented in tabular form with a description of the following: author and year of study, objectives of the study, general characteristics of the population, results and score on the PEDro scale.

The studies analyzed their methodological quality using the PEDro scale. The scale has 11 questions, in which only ten are scored. Thus, the score ranges from zero to ten. Each criterion is scored according to its presence or absence in the study assessed. Each satisfied item (except the first) contributes on one point to the total score. The items not described in the studies are classified as "not reported" and they are not scored. The final score is obtained by summing all the positive responses ${ }^{15}$. The studies indexed in the PEDro database already had methodological quality assessment. The studies not indexed in the PEDro were evaluated independently.

In a systematic review of studies, to be classified as "high quality", the study must have a score greater than $50 \%$ regarding its maximum possible score ${ }^{15}$. Thus, for the present review, all studies with scores greater than or equal to five points, were considered studies of high methodological quality. 


\section{RESULTS}

We found 61 articles in the electronic search in the databases. Selected these, 43 of them were excluded after applying the inclusion and exclusion criteria proposed. Besides these, seven articles were also excluded for not having sufficient methodological quality, according to the PEDro scale. Thus, as a result, 11 articles were selected for this review, which are summarized in Table 1.

We found only two papers ${ }^{11,16}$ which investigate directly the music and its effects on blood pressure, demonstrating a lack of studies related to the topic. Moreover, in five studies ${ }^{10,17-20}$, we found no statistically significant difference $(\mathrm{p}<0.05)$ on changes in blood pressure. Among the 11 studies that comprised the present study, only $45.5 \%$ observed reduction of variable blood pressure under influence of music.

Other related parameters such as oxygen saturation $\left(\mathrm{SpO}_{2}\right)$, heart rate (HR) and respiratory rate (RR) were, respectively, $50,57.1$ and $100 \%$ reduced among those studies that assessed these variables. Other variables such as QOL in individuals with hypertension ${ }^{11}$, pain relief in cancer patients ${ }^{17,21}$, reduced anxiety ${ }^{19}$ and factors such as levels of anesthetics in surgical patients ${ }^{10,19,20,22}$, post-traumatic stress associated with musical

Table 1: Characteristics of selected articles in the databases searched

\begin{tabular}{|c|c|c|c|c|}
\hline $\begin{array}{l}\text { Author } \\
\text { and year }\end{array}$ & Objectives & $\begin{array}{l}\text { Characteristics } \\
\text { of the population }\end{array}$ & Results & $\begin{array}{l}\text { Score } \\
\text { PEDro }\end{array}$ \\
\hline $\begin{array}{l}\text { Hatem, } \\
\text { Lira and } \\
\text { Mattos }^{10} \\
2006\end{array}$ & $\begin{array}{c}\text { To investigate the effect of music } \\
\text { on children in POI cardiac surgery } \\
\text { intensive care unit }\end{array}$ & $\begin{array}{c}48 \text { children of both sexes, } \\
\text { aged } 1 \text { day to } 16 \text { years of } \\
\text { age, evaluated for } 24 \mathrm{~h} \text { after } \\
\text { surgery }\end{array}$ & $\begin{array}{c}\text { We observed significant differences for } \\
\mathrm{HR} \text { and } \mathrm{RR} \text { between groups (intervention } \\
\text { and control) after the intervention. MAP, } \\
\text { temperature and } \mathrm{SpO}_{2} \text { showed no difference } \\
\text { between groups }\end{array}$ & 7 \\
\hline $\begin{array}{l}\text { Zanini } \\
\text { et al. }{ }^{11}, 2009\end{array}$ & $\begin{array}{c}\text { To evaluate the influence of } \\
\text { music therapy in the treatment of } \\
\text { hypertensive patients with respect to } \\
\text { QOL and BP control }\end{array}$ & $\begin{array}{c}45 \text { hypertensive patients, } \\
\text { men or women from a } \\
\text { group called the League of } \\
\text { Hypertension }\end{array}$ & $\begin{array}{c}\text { We observed significant improvement in QOL } \\
\text { and BP control in the experimental group, } \\
\text { compared from baseline to the end }\end{array}$ & 7 \\
\hline $\begin{array}{l}\text { Chafin } \\
\text { et al. }{ }^{16}, 2004\end{array}$ & $\begin{array}{c}\text { Assess whether the music is able to } \\
\text { decrease BP and HR after stress }\end{array}$ & $\begin{array}{l}75 \text { graduate students from } \\
\text { a U.S. university, } 52 \text { women } \\
\text { and } 23 \text { men }\end{array}$ & $\begin{array}{l}\text { During the mental task } \mathrm{HR} \text { and } \mathrm{BP} \text { increased } \\
\text { with the music and these variables stabilized } \\
\text { near the basal }\end{array}$ & 8 \\
\hline $\begin{array}{l}\text { Bittencourt } \\
\text { et al. } .^{17}, 2010\end{array}$ & $\begin{array}{l}\text { To evaluate the effect of classical } \\
\text { music on pain relief for children with } \\
\text { cancer before and after music therapy, } \\
\text { beyond the parameters BP and HR }\end{array}$ & $\begin{array}{l}10 \text { children aged } 4 \text { to } 16 \\
\text { years, } 10 \text { hospitalized } \\
\text { pediatric oncology sector in } \\
\text { the period July-October } 2007\end{array}$ & $\begin{array}{c}\text { BP and HR were stable before and after } \\
\text { music therapy. Pain intensity was significantly } \\
\text { lower after application of music }\end{array}$ & 8 \\
\hline $\begin{array}{l}\text { Nakahara } \\
\text { et al. }{ }^{18}, 2009\end{array}$ & $\begin{array}{c}\text { To investigate the effects of the } \\
\text { emotions evoked by music piano HR } \\
\text { and its variability }\end{array}$ & $\begin{array}{l}4 \text { women and } 6 \text { men college } \\
\text { physically active and healthy }\end{array}$ & $\begin{array}{c}\text { Music with emotion gave better answers than } \\
\text { music without emotion. No significant results } \\
\text { were found regarding the BP }\end{array}$ & 6 \\
\hline $\begin{array}{l}\text { Wang } \\
\text { et al. }{ }^{19}, 2009\end{array}$ & $\begin{array}{l}\text { Check if the music can influence the } \\
\text { anxiety of patients before surgery }\end{array}$ & $\begin{array}{l}93 \text { patients of both } \\
\text { genders, aged } 18-65 \text { years, } \\
\text { undergoing anesthesia and } \\
\text { surgical procedures }\end{array}$ & $\begin{array}{l}\text { BP and HR showed no significant differences. } \\
\text { After the intervention, individuals in the music } \\
\text { group reported significantly lower levels of } \\
\text { anxiety compared to the control group }\end{array}$ & 7 \\
\hline $\begin{array}{l}\text { Lewis, } \\
\text { Osborn and } \\
\text { Roth }^{20}, 2004\end{array}$ & $\begin{array}{c}\text { Confirm whether patients undergoing } \\
\text { general anesthesia exposed to a } \\
\text { musical recording during surgery, } \\
\text { had less need for anesthetics during } \\
\text { surgery }\end{array}$ & $\begin{array}{l}60 \text { patients, both sexes } \\
\text { underwent laparoscopic } \\
\text { surgical procedures or a } \\
\text { lumbar American medical } \\
\text { school }\end{array}$ & $\begin{array}{l}\text { Patients who listened to music recording } \\
\text { required a third less analgesia than the } \\
\text { control group. There were no significant } \\
\text { differences in mean BP and RR }\end{array}$ & 8 \\
\hline $\begin{array}{l}\text { Franco and } \\
\text { Bezerra }^{21} \\
2009\end{array}$ & $\begin{array}{l}\text { To evaluate the perception of cancer } \\
\text { patients with chronic pain about the } \\
\text { effect of music on pain relief }\end{array}$ & $\begin{array}{l}50 \text { patients with cancer and } \\
\text { age above } 20 \text { years, male } \\
\text { or female }\end{array}$ & There was a reduction in $B P, H R$ and $R R$ & 6 \\
\hline $\begin{array}{l}\text { Camara and } \\
\text { Ruszkowski22, } \\
2008\end{array}$ & $\begin{array}{l}\text { Determine the effect of live classical } \\
\text { piano music on vital signs of patients } \\
\text { undergoing ophthalmic surgery }\end{array}$ & $\begin{array}{l}203 \text { patients of both } \\
\text { sexes undergoing various } \\
\text { ophthalmic procedures in a } \\
\text { medical center }\end{array}$ & $\begin{array}{c}\text { There was a decrease in } \mathrm{BP}, \mathrm{HR} \text { and } \mathrm{RR} \\
\text { in the operating room compared with the } \\
\text { preoperative period. The control group } \\
\text { showed a significant increase in MAP, HR and } \\
\text { RR intraoperative }\end{array}$ & 5 \\
\hline $\begin{array}{l}\text { Pugginal } \\
\text { and Silva } \\
2009\end{array}$ & $\begin{array}{l}\text { To investigate the influence of music } \\
\text { and voice message about the vital } \\
\text { signs of patients and facial expression } \\
\text { in physiological or induced coma }\end{array}$ & $\begin{array}{c}30 \text { patients admitted to } \\
\text { the intensive care unit of } \\
\text { a teaching hospital in São } \\
\text { Paulo }\end{array}$ & $\begin{array}{c}\text { There were significant differences in the signs } \\
\mathrm{SpO}_{2} \text { and RR. No significant results were } \\
\text { found regarding BP }\end{array}$ & 6 \\
\hline $\begin{array}{l}\text { Bernardi, } \\
\text { Porta and } \\
\text { Sleight }{ }^{24} \\
2006\end{array}$ & $\begin{array}{l}\text { Investigate the answers to six types of } \\
\text { music in musicians and no musicians }\end{array}$ & $\begin{array}{l}24 \text { healthy subjects, } \\
\text { musicians and no } \\
\text { musicians, volunteers and } \\
\text { medical students, male }\end{array}$ & $\begin{array}{c}\text { Ventilation, PA, FC, middle cerebral artery flow } \\
\text { and decreased baroreflex with faster tempos } \\
\text { and simpler rhythmic structures compared } \\
\text { with baseline. BP declined to break. Musicians } \\
\text { showed greater respiratory sensitivity to the } \\
\text { music than the non-musician ones }\end{array}$ & 6 \\
\hline
\end{tabular}

BP: blood pressure; HR: heart rate; RR: respiratory rate; $\mathrm{SpO}_{2}$ : oxygen saturation; $\mathrm{QOL}$ : quality of life; MAP: mean arterial pressure; POI: postoperative; h: hours. 
stimulation ${ }^{16}$, induced coma situations ${ }^{23}$ and influence of music on musicians and no musicians ${ }^{24}$ were also targets of selected articles in this review.

The studies analyzed investigated responses to different musical styles, namely, slow classical music, fast classical music, twelvetone music, Techno, rap and raggae music, in individuals of both sexes, with ages ranging from one day of birth, past children aged four to 16 years, young graduates, to 65 -year-old seniors.

Finally, the average score obtained, by applying the PEDro scale, was $6.73 \pm 1.01$ points, meaning it can be stated that the articles showed highly acceptable methodological quality, though not outstanding, since the maximum score is 10 points.

\section{DISCUSSION}

In general, the analysis of texts selected for this review suggests that music can have a real role in the regulation of blood pressure through its neural processing. This modulation occurs, largely, by the activity of the autonomic nervous system, as well as its branches, the sympathetic and parasympathetic nervous system, acting directly on the cardiovascular system components.

Anatomically, the primary acoustic circuit in humans consists of the auditory nerve, brain, thalamus (medial geniculate body) and auditory cortex. The sound stimulus is picked up by the outer ear that conducts sound energy by the canal toward the eardrum. This membrane transmits vibrations to the ossicles in the middle ear (hammer, anvil and stirrup), generating mechanical energy ${ }^{25}$.

The auditory nerve makes synapses with neurons in the cochlear nucleus until the action potential reaches the brain. In the cochlear nucleus, the action potential goes to the medial geniculate body (auditory thalamus) and then follows up to the auditory cortex ${ }^{25}$. This is located in the transverse spin, Helsh, the lateral fissure.

The auditory cortex performs a perceptive analysis of the music, extracting specific information about their acoustic characteristics, such as pitch, timbre, intensity and roughness ${ }^{26}$.

The musical functions are complex, multiple and asymmetric, involving the right hemisphere for pitch, timbre and melodic discrimination and the left hemisphere for rhythms, melody semantic identification, sense of familiarity, sequential and temporal processing of sounds ${ }^{27}$.

Faced with a musical stimulus, individuals create positive or negative expectations based on their cultural, emotional, social and environmental interactions. Thus, if music meets positive expectations, subjects relax, however, if the same matches in a negative way, the person may be under tension. Thus, through the succession of expectations met or frustrated with their relaxation or tension results, it is formed the basis of the neurophysiological responses to music, raising or normalizing blood pressure ${ }^{28}$.
By stimulating the brain, the limbic system of sound will act, more specifically, in the amygdaloid complex, a region involved in processing emotions. This complex, in a situation of stress, fear or sadness, stimulates the hypothalamic neurons, and consequently stimulates the anterior pituitary gland to release adrenocorticotropic hormone (ACTH) into the bloodstream, reaching the adrenal glands, which then releases the cortisol hormone, known as the stress hormone ${ }^{21}$.

The autonomic nervous system (ANS) is another neural component that has direct relation with the neurophysiological responses to musical stimuli ${ }^{29}$. It is divided into the sympathetic nervous system (SNS) and parasympathetic nervous system (PNS), and provides innervation to all body organs, glands, smooth muscle and cardiac muscle. The SNS prepares the body for fight or flight, through physiological changes in blood pressure, heart rate and breathing ${ }^{30}$.

Modulation of sympathetic and parasympathetic nervous system is involved in at least three reflex arcs, namely: 1) reflex arcs involving the arterial baroreceptors (receptors present on the system of high blood pressure - high circulation); 2) reflex pathways related to cardiopulmonary receptors (low system pressure - small circulation); and 3) reflex arcs related to arterial chemoreceptors (central and peripheral) ${ }^{30,31}$. These reflex responses of the sympathetic and parasympathetic allow adjustment of cardiac output and peripheral vascular resistance, contributing to the stabilization and maintenance of systemic blood pressure during different physiological situations ${ }^{30,31}$.

The parasympathetic, or vagal activity, exerts inhibitory effects or depressants, translated by bradycardia due to sinus node inhibition, depression of atrioventricular conduction, depression of excitability of specialized conductive fibers and myocardial inotropism and depression. These effects contributed to the relative electrophysiological heart balance, becoming then antiarrhythmogenic factors and providing a stabilization of blood pressure ${ }^{32}$.

Cardiovascular responses to sound can be triggered by many ways, and one example is the startle response, mediated by a brainstem circuit. The acoustic startle, a well-known effect of loud sounds on the cardiovascular system, is described as the sudden heart rate and blood pressure response to an excessively high sound stimulation. A typical intensity, used to elicit a startle reflex, is $110 \mathrm{~dB}$, being this a much higher intensity than the ambient noise. However, the responses to cardiac acceleration, commonly used in clinical trials, observed that some individuals have been exposed to stimuli at 60 and $110 \mathrm{~dB}$ noise. The increase in blood pressure and heart rate, in response to acoustic startle stimuli, indicates an autonomic function to respond to acoustic stimuli ${ }^{29}$.

It is believed that there is a correlation between the operation of the SNS, the emotions and hypertension, since brain areas related to emotional behavior, they occupy very wide 
territories on the telencephalon and diencephalon, in which structures that are part of the limbic system, such as the prefrontal area and hypothalamus, through the ANS, regulate the visceral activities ${ }^{32}$.

The mechanism of blood pressure regulation composes complex physiological functions, depending on the system of integrated cardiovascular, renal, neural and endocrine systems. This regulation is the result of the activity of feedback systems, which operate in short and long terms. The main control mechanism in the short term is played by reflexes that are originated in the arterial baroreceptors, and stretch receptors into the cardiopulmonary region ${ }^{30,31}$.

Factors related to the ANS may be influenced by the music, making it a modulator of this system, influencing blood pressure. When music meets the expectations of the subject, they are able to relax through the ANS balance between sympathetic and parasympathetic. When the music does not meet expectations, the subject can get tense due to the SNS and reverse the action of $\mathrm{PNS}^{28}$.

Another factor that could explain the blood pressure regulation through music is the decreased release of catecholamine (adrenaline and noradrenaline), inducing vasodilation, among other factors, which consequently result in a decrease in blood pressure $\mathrm{e}^{16,25}$.

In summary, the studies selected for this review have shown that musical stimulation produces cardiovascular changes, induced by central physiological mechanisms, which are dose-dependent factors, such as musical style, the physical condition of the subject, and the time and intensity of exposure. Such findings are important for health professionals, since music can be used as an adjunct in the treatment of various diseases and disorders, becoming thus the appropriate knowledge of their effects on the human body, for a proper prescription. In this context, the music therapist is a professional who can contribute to the health teams, training it, in order to act in different contexts and in different clinical hospital situations.

In conclusion, the results suggest that music can regulate blood pressure levels through its neural processing, by decreasing sympathetic activity, associated with an increase in vagal activity, producing bradycardia, decreasing total peripheral resistance and cardiac output, and contributing to maintaining blood pressure at normal levels.

\section{REFERENCES}

1. Corrêa AGD, Ficheman IK, Nascimento M, Lopes RD. O uso da tecnologia de realidade aumentada no apoio ao processo de reabilitação em sessões de musicoterapia. Rev Bras Inov Tecnol Saúde. 2011;1(3):1-14.

2. Delecrode FS, Pereira LC, Viviani AG. Estudo dos efeitos da música após fisioterapia respiratória. Ter man. 2009;31(7):192-6.

3. Lord VM, Cave P, Hume VJ, Flude EJ, Evans A, Kelly JL, et al. Singing teaching as a therapy for chronic respiratory disease: a randomized controlled trial and qualitative evaluation. BMC Pulm Med. 2010;10:41.

4. Côrte B, Lodovici Neto P. A musicoterapia na doença de Parkinson. Ciênc Saúde Coletiva. 2009;14(6):2295-304

5. Särkämö T, Tervaniemi M, Laitinen S, Forsblom A, Soinila S, Mikkonen $\mathrm{M}$, et al. Music listening enhances cognitive recovery and mood after middle cerebral artery stroke. Brain. 2008; 131(3):866-76

6. Von Leupoldt A, Taube K, Schubert-Heukeshoven S, Magnussen H, Dahme B. Distractive auditory stimuli reduce the unpleasantness of dyspnea during exercise in patients with COPD. Chest. 2007;132(5):1506-12.

7. Bauldoff GS, Rittinger M, Nelson T, Doehrel J, Diaz PT. Feasibility of distractive auditory stimuli on upper extremity training in persons with chronic obstructive pulmonary disease. J Cardiopulm Rehabil. 2005;25(1):50-5

8. Bernartzky G, Bernatzky P, Hesse HP, Staffen W, Ladurner G. Stimulating music increases motor coordination in patients afflicted with Morbus Parkinson. Neurosci Lett. 2004;361(1-3):4-8.
9. Emery CF, Hsiao ET, Hill SM, Frid DJ. Short-term effects of exercise and music on cognitive performance among participants in a cardiac rehabilitation program. Heart Lung. 2003;32(6):368-373.

10. Hatem TP, Lira PC, Mattos SS. The therapeutic effects of music in children following cardiac surgery. J Pediatr. 2006;82(3):186-92.

11. Zanini CRO, Jardim PCB, Salgado CM, Nunes MC, Urzêda FL, Carvalho MVC, et al. O Efeito da Musicoterapia na qualidade de vida e na pressão arterial do paciente hipertenso. Arq Bras Cardiol. 2009;93(5):534-40

12. Sutoo D, Akiyama K. Music improves dopaminergic neurotransmission: demonstration based on the effect of music on blood pressure regulation. Brain Res. 2004;1016(2):255-62.

13. Cervellin G, Lippi G. A journey with Euterpe. Sinfonia concertante for music, heart and brain. Recenti Prog Med. 2011;102(9):352-8.

14. Johnsen EL, Tranel D, Lutgendorf S, Adolphs R. A neuroanatomical dissociation for emotion induced by music. Int J Psychophysiol. 2009;72(1):24-33

15. Helenice JCG, Coury RFC, Moreira NBD. Efetividade do exercício físico em ambiente ocupacional para controle da dor cervical, lombar e do ombro: uma revisão sistemática. Rev Bras Fisioter. 2009;13(6):461-79

16. Chafin S, Roy M, Gerin W, Christenfeld N. Music can facilitate blood pressure recovery from stress. Brit J Health Psych. 2004;9(3):393-403.

17. Bittencourt WS, Salício MA, Pinheiro SF, Lell D. O efeito da música clássica no alívio da dor de crianças com câncer. Rev Uniciências. 2010;14(1):95-111. 
18. Nakahara H, Furuya S, Obata S, Masuko T, Kinoshita H. Emotion-related changes in heart rate and its variability during performance and perception of music. Ann NY Acad Sci. 2009;1169(7):359-62.

19. Wang SM, Kulkarni L, Dolev J, Kain ZN. Music and preoperative anxiety: A randomized, controlled study. Anesth Analg. 2002;94(6):1489-94.

20. Lewis AK, Osborn IP, Roth R. The effect of hemispheric synchronization on intraoperative analgesia. Anesth Analg. 2004;98(2):533-6.

21. Franco M, Bezerra AR. Music therapy in relief of pain in oncology patients. J Einstein. 2009;7(2):147-51.

22. Camara JG, Ruszkowski JM, Worak SR. The effect of live classical piano music on the vital signs of patients undergoing ophthalmic surgery. Medscape J Med. 2008;10(6):149-58.

23. Pugginal ACG, Silva MJP. Sinais vitais e expressão facial de pacientes em estado de coma. Rev Bras Enferm. 2009;62(3):435-41.

24. Bernardi L, Porta C, Sleight P. Cardiovascular, cerebrovascular, and respiratory changes induced by different types of music in musicians and non-musicians: the importance of silence. Heart. 2006;92(4):445-52.
25. Boso M, Politi P, Barale F, Emanuele E. Neurophysiology and neurobiology of the musical experience. Funct Neurol. 2006;21(4):187-91.

26. Koelsch S, Fritz T, Schulze K, Alsop D, Schlaug G. Adults and children processing music: an fMRl study. Neuroimage. 2005;25(4):1068-76.

27. Muszkat M, Correia CMF, Campos SM. Música e neurociências. Rev Neurocienc. 2000;8(2):70-5.

28. Miranda MLJ, Godeli MRCS. Música, atividade física e bem-estar psicológico em idosos. Rev Bras Cienc Mov. 2003;11(4):80-7.

29. Valenti VE, Guida HL, Frizzo ACF, Cardoso ACV, Vanderlei LCM, Abreu LC. Auditory stimulation and cardiac autonomic regulation. Clinics. 2012;67(8):955-8.

30. Vanderlei LCM, Pastre CM, Hoshi RA, Carvalho TD, Godoy MF. Noções básicas de variabilidade da frequência cardíaca e sua aplicabilidade clínica. Rev Bras Cir Cardiovasc. 2009;24(2):205-17.

31. Valenti VE, Sato MA, Ferreira C, Abreu LC. Regulação neural do sistema cardiovascular: centros bulbares. Rev Neurocienc. 2007;15(4):317-20.

32. Fonseca FCA, Coelho RZ, Nicolato R, Malloy-Diniz LF, Silva Filho HC. A influência de fatores emocionais sobre a hipertensão arterial. J Bras Psiquiatr. 2009;58(2):128-34. 